International Journal of Social Sciences and Humanities
Available online at http://sciencescholar.us/journal/index.php/ijssh
Vol. 2 No. 2, August 2018, pages: $15 \sim 25$
e-ISSN: 2550-7001, p-ISSN: 2550-701X
http://dx.doi.org/10.29332/ijssh.v2n2.115

\title{
Interactive Lesson Study as a Competence Indicator of Prospective English Teachers
}

\author{
$\underset{\text { CrossMark }}{\text { teich tor underey }}$

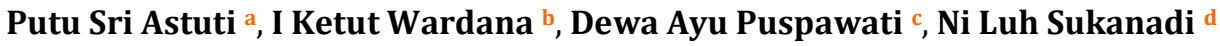 \\ Article history: Received 9 August 2017, Accepted in revised form 1 March 2018, Approved 17 April 2018, \\ Available online 2 May 2018
}

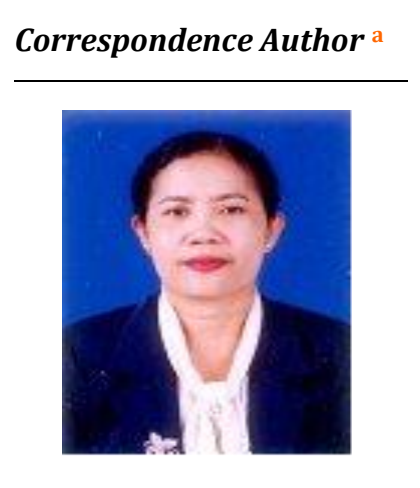

Keywords

Communicative;

Instruction;

Learning attitudes;

Learning;

Lesson study model;

\begin{abstract}
The present study aims at investigating the competence level of prospective English teachers through interactive lesson study which involved supervisions of teachers, lecturers, and student teachers themselves. A Classroom Action Research in the form of interactive lesson study model was conducted in four steps, namely planning, practicing, observing, and reflecting. Moreover, the research was administered in two cycles. Some instruments used in data collection were rubric of teaching practice, character checklist, questionnaire, and participatory observation form. The effectivity of approach could be analyzed based on the average scores of 30 student teachers yielded randomly in each cycle, which gradually increased compared to their pre-tests after interactive lesson study has been applied. In the first cycle, the competence of student teachers started to improve with the total score of 1730 and an average score of 58 for the attitude aspect, the total score of 2169 and an average score of 72 for the knowledge aspect, and the total score of 2198 and an average score of 73 on the skill aspect. The achievement of the students' score in cycle 1 was 68 with the medium category. In the second cycle, changes in student learning attitudes began to show significant improvement: total score of 2390 on attitude aspect with a mean of 80 , a total score of 2416 on knowledge aspect with a mean of 81, and a total score of 2457 on skill aspect with a mean of 83 . Student score gained in cycle II was 82 with the high category. In a nutshell, the ability of the students on their learning attitudes, knowledge, and writing skills were specified as high category with cultural attitude.
\end{abstract}

e-ISSN : 2550-7001, p-ISSN : 2550-701X ${ }^{\odot}$ Copyright 2018. The Author. SS Journals Published by Universidad Técnica de Manabí. This is an open-access article under the CC BY-SA 4.0 license (https://creativecommons.org/licenses/by-sa/4.0/) All rights reserved.

\footnotetext{
a Faculty of Teacher Training and Education, Universitas Mahasaraswati Denpasar, Bali, Indonesia

b Faculty of Teacher Training and Education, Universitas Mahasaraswati Denpasar, Bali, Indonesia

c Faculty of Teacher Training and Education, Universitas Mahasaraswati Denpasar, Bali, Indonesia

d Faculty of Teacher Training and Education, Universitas Mahasaraswati Denpasar, Bali, Indonesia
} 


\section{Contents}

Abstract

1. Introduction

2. Research Method

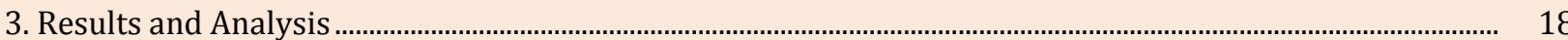

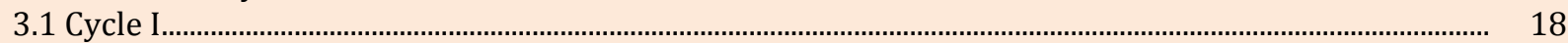

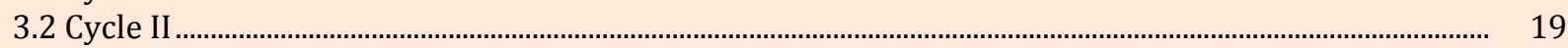

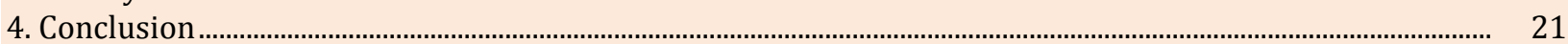

Conflict of interest statement and funding sources.........................................................................................

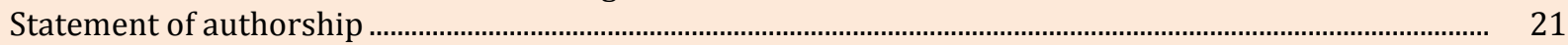

Acknowledgements.............................................................................................................................................. 21

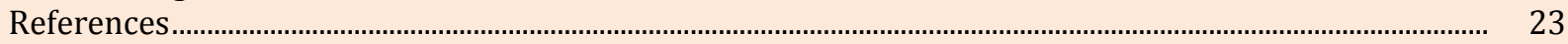

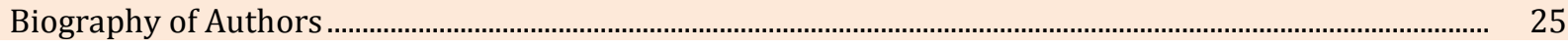

\section{Introduction}

The quality of education depends largely on the performance of teachers in developing the potential of learners. The professionalism of subject teachers plays a very important role for the advancement of national education thus the process of undertaking the educational qualifications of prospective teachers in teacher education should intensively and creatively draw and develop the science of teaching pedagogy. Indonesian Education Law No. 14 the Year 2005 about teachers and lecturers states that teachers are professional educators with their primary tasks of educating, teaching, guiding, directing, training, assessing and evaluating learners in early childhood education on formal education, primary education, and secondary education. Therefore, prospective teachers should own intelligence which includes pedagogical and social intelligence (Mantra, 2017; Maba \& Mantra, 2018).

In the process, students sometimes find it difficult to absorb knowledge from their lecturers but they gain a better understanding as they involve directly in the learning process. According to Davis (2003), student teachers tend to learn more from how they are taught by their lecturers and not from what the lecturers have described how to teach well. The lecturers should give real examples of how to learn, participate as observers or observe videotapes to improve the ability of prospective students in delivering materials. Meanwhile, Hindustan (2005:8) elaborates training programs in education (in-service training) which has been implemented so far has separated teaching methods and materials. The discussion of methods or model application and learning materials are usually not accompanied by contextual examples. The subject matters discussed were highly academic and apart from the learning context. This condition causes teacher candidates face difficulties in applying what he or she has obtained from their education or training.

In learning theory, learning is defined as a result of interaction between stimulus and response (Slavin, $2000: 143)$. A person is considered to have learned something if he can show changes in his behavior. Some most important skills a teacher needs to have are the skills to open lessons, activate students, and transfer the subject matter. Opening the lessons is often defined only as a number of activities when teachers enter the classroom. Lesson themselves have several components, namely attracting students' attention, giving motivation, and giving a reference. This is done mainly to link up the students' prior knowledge (Maba, 2017; Mantra, 2017)

However, the problems often encountered by teacher candidates were planning the lesson, mastering the classroom, understanding the instructional materials, and mapping students' abilities. As a consequence, micro-teaching lessons and teaching practicum has been passed without any meaningful impacts to student teachers in schools or laboratories. One of the factors was learning methods and attitude modeling performed by the lecturers in the classroom. Prospective teachers should be able to stimulate learners' knowledge so that they cannot associate knowledge in their language with the assigned tasks. They should seek breakthroughs in applying innovative methods in the process of improving writing skills and attitude modeling as a guidance for learners. One of the recommended methods is the application of interactive lesson study model.

Lesson study is a model of teacher professional development through collaborative and sustainable learning, based on the principles of colleagues and mutual learning to build a learning community. This 
means that lesson study is not a method or learning strategy, but it provides opportunities to apply various updates of learning in line with the situation, condition, and problem faced by teachers. This model is known as the secret of Japanese success in improving the quality of education (Stigler \& Hiebert, 1999:109). The main principle of lesson study is the gradual improvement of learning quality by learning from one's own experience and others' in the context of the closed environment. Lesson study emphasizes learning to know towards learning to do and leads towards learning to live together.

The implementation of teaching by teacher candidates through lesson study was conducted in four stages, supplemented with materials related to daily life, namely: planning (PLAN), practicing (DO), observing (OBSERVE) and criticizing (REFLECTION). Learning process provided by prospective teachers during practicum activities can embed the basic concepts of understanding and apply them to the real life of learners. Thus, they gain some learning experience which does not only improve their performance but also affect their lives in the future. The lesson study itself is not only beneficial for students but also for the professional development of prospective teachers involved. Therefore, lesson study can be used as an alternative to existing teacher training programs.

Based on the aforementioned explanation, the research focuses on the process of developing prospective teachers' skills. Furthermore, research lecturers and English teachers in schools were using the model of lesson study based on habit formation learning system in order to improve teaching competence of student teachers. The research was expected to provide more detailed information about the results and impacts, both for prospective teachers involved and sustainability of quality education. Thus, problem-solving was offered in the form of action through the implementation of lesson study based on habit formation learning system. The research problems can be formulated as follows 1) the ability of English teacher candidates after the implementation of interactive lesson study model and 2) the attitude of English teacher candidates after the implementation of interactive lesson study. The research aims at investigating the implementation of lesson study to determine the changes of teaching process done by prospective teachers, especially in interacting with students and among prospective teachers, with the following characters: honest, responsible, and cooperative in interacting with student teachers and between student teachers.

There were several relevant studies reviewed as empirical references. The first research is a study conducted by Wilujeng (2012) entitled "Integrated Science Model Based on Local Technology and Local Wisdom to Foster the Realisation of Outdoor Learning System". This model was designed in a form of outdoor learning which could demonstrate the nature of science learning: in an integrated and thematic way, and used to overcome problems of the young generation about moral degradation (appreciation of technology, culture, and local wisdom) as well as the manifestation of resources and learning environment in the community. Consequently, Enrichment of best attitude practices becomes a vital role in successful learning (Mantra \& Maba, 2018).

The second research was written by Widodo et al. entitled "The role of lesson study in improving the teaching ability of prospective teachers". The purpose of this research was to discover the improvement of teaching ability of student teachers through lesson study which was based on video camera. Based on the questionnaire observation, the emotional climate of teaching from student teachers was quite good. Meanwhile, the learning experiences through lesson study made them understand and provided meaningful perspectives to improve their teaching competence. Teachers in this respect are continually required to enhance their competence to deal with everlasting changes of educational needs (Mantra, 2017)

The lesson study was implemented in 3 stages, namely planning (plan), implementing (do), and reflecting (see). Through these stages, the lesson study is a continuous quality improvement activity. At the planning stage (plan), student-centered learning activities were designed to encourage student teachers to participate actively. Good planning was done in the collaboration of several teachers and lecturers to enrich ideas as well as among teachers. Planning began by analyzing the problems faced by teachers in learning. This case might be based on subject matters that still need to be explored by the teachers, or pedagogy which includes approach, methods, media, strategy, and evaluation of learning. Problems relating to the approach and method were basically sourced in conformity with the characteristics of learning materials the teacher needs to know. Problems on media and learning strategies were closely related to the availability of learning facilities that teachers could use to achieve learning objectives. The

Astuti, P., Wardana, I., Puspawati, D., \& Sukanadi, N. (2018). Interactive lesson study as a competence indicator of prospective English teachers. International Journal Of Social Sciences And Humanities (IJSSH), 2(2), 15-25.

doi:10.29332/ijssh.v2n2.115 
problem of learning evaluation was closely related to the teacher's knowledge about the method of measuring the achievement of competency standard (SK) and basic competence (KD) of the students, based on standard of content included in the Regulation of the Ministry of National Education (Permendiknas) No 22/2005 composed by the National Education Standards Agency (BSNP) of the Ministry of National Education of Indonesia. In this case, the teacher needs to deepen his knowledge about various ways of evaluation in the field of study. The framework of this study mainly consisted of planning, Doing, and seeing.

\section{Research Methods}

This research was conducted at a private university in Bali. A sample of this research was 30 students (18 male and 12 male) of the sixth semester, selected randomly from the total of 200 students. In accordance with the character of the research problems, objectives or targets wanted to be achieved, this study was categorized as a classroom action research. Action research can be interpreted as an objective, systematic, and controlled study to observe the effectiveness of an action. Actions of improvement in the learning process were implemented through several cycles, each consisting of three learning sessions. Each session has four interconnected steps, such as planning, taking action, observing and reflecting.

Three types of instruments used to collect research data were test, checklist of learning attitudes, observation sheet, and questionnaire with active participation observation method. There were two groups of tests used based on their different functions, namely 1) a pre-test was used to measure students' ability prior to applying the teaching methods and techniques and 2) a post-test was conducted to measure the effectiveness of interactive lesson study. While the checklist of learning attitudes served to investigate the students' real attitude in the teaching and learning process, the data was yielded before and after the action is applied at the end of the cycle. To discover the level of active participation, an observation sheet was designed by teachers, lecturers, and prospective teachers and questionnaire were disseminated at the end of the cycle to yield students' response during the learning method. The data was collected in the forms of scores (pre-test and post-test) and was analyzed by using descriptive statistic approach, i.e. by determining the value of the mean, median, and mode. The scores especially their competence and performance.

\section{Results and Analysis}

The success and effectiveness of the learning model are determined by the output of the action process in the learning activities. The researchers focused on improving the characterization of English proficiency through lesson study on the text about daily activities. The research used the quantitative approach with descriptive analysis because the data is presented in the form of numbers, pictures, and sentence sequences. The data of this study was yielded from the students' performance in teaching before and after the action. The data show three competencies of student teachers, such as learning attitude, knowledge, and skills. The data were obtained by using observation sheets, pre-test, and structured questionnaires with 10 statements concerning the action process. The test consisted of diagnostic tests, performance tests, and portfolio. The results of pre-test reveal that the ability of students was still lacking, shown by the score of 63, while their attitude was still lacking discipline and responsibility. Thus, reconstructions of lesson study in order to collect more data were done in several cycles.

\subsection{Cycle I}

Based on the results of reflection on the aforementioned initial study, the cycle I have been implemented in 2 sessions by applying character models from the text about daily activities. In each session, there were 4 steps of implementation: planning, action, observation, and reflection. All actions in the application of learning, observation, and reflection models were planned in details, i.e. preparation of lesson plan, questions, provision of observation sheets and questionnaires, material gathering, and corrective design.

In the implementation of research, the researchers grouped the student teachers into 6 groups consisting of 5 students. They read the ways to compose syllabus and lesson plan. Subsequently, each member selected a topic and method of teaching via other group discussions. Student teachers then taught their peers and junior high school students. The lecturers themselves engaged in peer reviews. Finally, the 
lecturers and student teachers provided input while teachers gave score. At the same time, teachers and researchers observed student teachers' learning attitudes. In the end of student teachers' action, a posttest was given to measure their learning attitude, knowledge, and English writing skills. To provide complete information about the initial state of student teachers' achievement, a summary of the preliminary results was analyzed and presented in the following table.

Table 1

The summary of scores of attitudes, knowledge, and teaching skills of student teachers in cycle I

\begin{tabular}{cccccc}
\hline $\begin{array}{c}\text { Research } \\
\text { Subject }\end{array}$ & $\begin{array}{c}\text { Score of } \\
\text { attitude } \\
\text { aspect }\end{array}$ & $\begin{array}{c}\text { Score of } \\
\text { knowledge } \\
\text { aspect }\end{array}$ & $\begin{array}{c}\text { Score of skill } \\
\text { aspect }\end{array}$ & $\begin{array}{c}\text { Average } \\
\text { Value }\end{array}$ & Details \\
\hline Total Score & 1730 & 2169 & 2198 & - & - \\
Mean Score & 58 & 72 & 73 & 68 & medium \\
\hline
\end{tabular}

To corroborate the information of student teachers' attitude changes, researchers observed them in forms of group and individual tasks, then all student teachers were observed by using structured observation instrument. The results of this observation were then analyzed into the percentage of student teachers who were active, cooperative and responsible, as presented in the following table.

Table 2

The percentage of learning attitudes of student teachers during the implementation of lesson study in cycle I

\begin{tabular}{llll}
\hline No & Observed Components & Total & $\%$ \\
\hline 1 & Student teachers with active participation & 16 & $53 \%$ \\
2 & Cooperative student teachers & 20 & $70 \%$ \\
3 & Student teachers who could finish the assignments & 23 & $73 \%$ \\
\hline
\end{tabular}

\subsection{Cycle II}

Based on the learning outcomes in cycle I, the researchers composed a reflection of action because there were still many students who have not achieved a complete learning minimum score. It means that their attitudes, knowledge, and skills need to be improved. Further, solutions to the problems they faced should also be provided. There were some major improvements needed in these three aspects of competence: 1) providing additional training, 2) simplifying explanations, 3) using media, and 4) providing motivation to students who need to retake the exam. Moreover, applying the character model through lesson study in the text about daily activities has been held in 2 sessions on the second cycle. In each session, there were four steps of implementation: revised planning, action, observation, and reflection.

In the research implementation, researchers carried out the same strategy but highlighted some things related to the main improvements which have been designed. This study grouped students into several groups consisting of 5 students. They read the text about daily activities and sought for the moral message of the story. Subsequently, they translated the text into Indonesian. Students then matched and chose the behavior found in the story and tried to connect with their own behavior so far. Finally, all students translated the text into English and searched for adjectives which matched their characters. At the same time, teachers and researchers observed students' learning attitudes. Then, the researchers checked the task and together with the students constructed the translation. At the end of the action, the learners were given a post-test which measured their English language attitudes, knowledge, and skills. The time given for doing them was just one hour. All results of the post-test were examined, assessed, and analyzed to

Astuti, P., Wardana, I., Puspawati, D., \& Sukanadi, N. (2018). Interactive lesson study as a competence indicator of prospective English teachers. International Journal Of Social Sciences And Humanities (IJSSH), 2(2), 15-25. doi:10.29332/ijssh.v2n2.115 
obtain the average score. Finding the average score, researchers then counted the number of students who have reached the minimum range of score. The raw scores and summary of learning outcomes in cycle I are presented in the following table.

Table 3

The summary of scores of attitudes, knowledge, and teaching skills of student teachers in cycle II

\begin{tabular}{cccccc}
\hline $\begin{array}{c}\text { Research } \\
\text { Subject }\end{array}$ & $\begin{array}{c}\text { Score of } \\
\text { attitude } \\
\text { aspect }\end{array}$ & $\begin{array}{c}\text { Score of } \\
\text { knowledge } \\
\text { aspect }\end{array}$ & $\begin{array}{c}\text { Score of skill } \\
\text { aspect }\end{array}$ & $\begin{array}{c}\text { Average } \\
\text { Value }\end{array}$ & Details \\
\hline Total Score & 2390 & 2416 & 2457 & - & - \\
Mean Score & 80 & 81 & 83 & 82 & high \\
\hline
\end{tabular}

Based on the summary of learning outcomes after the lesson study reconstruction models were applied, students' attitudes, knowledge, and writing skills increased gradually. It was seen from the average score and percentage of complete learning mastery. For the three competencies, the subjects of research should at least reach the score of complete learning mastery (KKM), which was around 75. The success indicator of this research was determined from the percentage of achievement of KKM, which reached more than $80 \%$ obtained from 40 students. In a nutshell, the lesson study reconstruction model was very effective in sharpening the level of understanding, increasing the ability to write in English, and changing the attitude of learners. For the record of character changes and learning attitudes, this study was stopped as the students' attitudes have reached the score of more than the percentage of minimum consistency (50\%). The summary is presented in the following table.

Table 4

The percentage of learning attitudes of student teachers during the implementation of lesson study in cycle II

\begin{tabular}{llll}
\hline No & Observed Components & Jumlah & $\%$ \\
\hline 1 & Students with active participation & 25 & $83 \%$ \\
2 & Cooperative students & 25 & $83 \%$ \\
3 & Students who could finish the assignments & 27 & $90 \%$ \\
\hline
\end{tabular}

To discover the learning attitude and effectiveness of methods used in the lesson study about daily activities, a chart is presented.

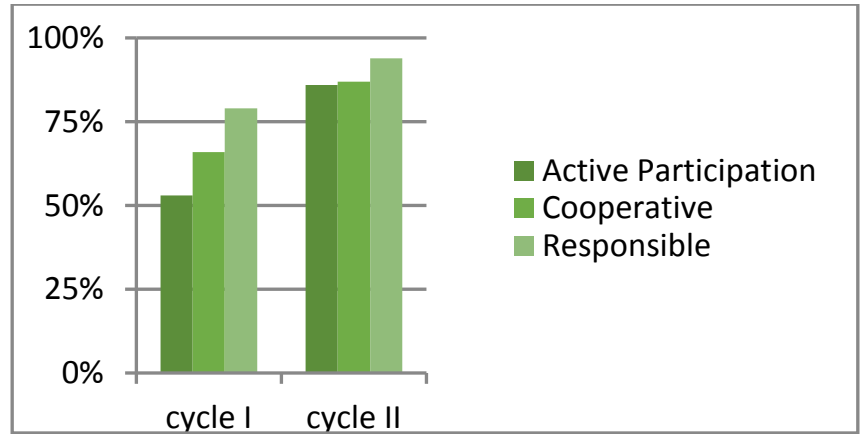

Chart 1

The percentage of learning attitudes of student teachers in the implementation of lesson study in cycle I and II 


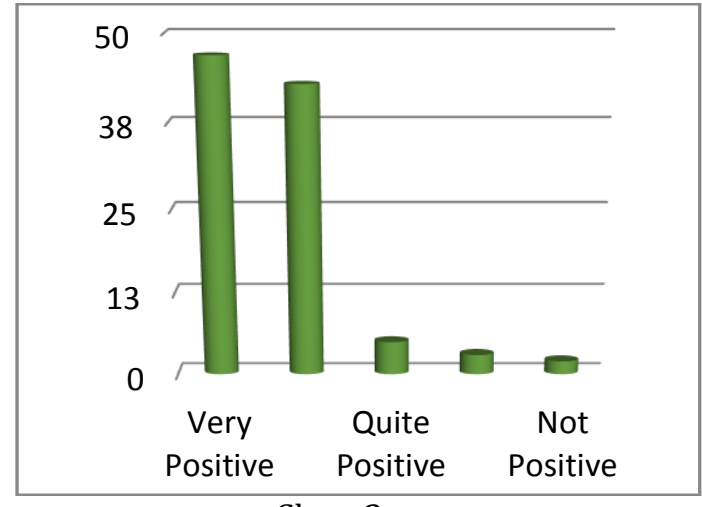

Chart 2

The percentage of student teachers' response in the English teaching process through lesson study

The formulated research questions directed the research into exploring the learning attitude, knowledge, and skill of students in writing using English through interactive lesson study. From the pre-test results, it was found that the ability of 30 students in applying teaching methods was adequate. Then, the reconstruction of lesson study model with four stages (e.g. planning, implementing, observing, and reflecting) was conducted. In cycle 1, students' ability began to increase with the total score of 1730 in attitude aspect with mean of 58, total score 2169 in knowledge aspect with mean of 72, and total score 2198 in skill aspect with mean of 73. Students' score in cycle 1 was 68 thus it was categorized as "medium". Students' learning attitude score showed that 16 students (53\%) were participating actively, 20 students (66\%) were cooperative students, and 23 students (79\%) were noted as responsible ones. This result led to reflection by providing additional training for those who gained low score and enrichment for those who were categorized as a medium achiever. For attitude aspect, motivation modeling approach was implemented. In cycle 2, it was noted that changes in students' learning attitudes began to show significant improvement. The total score 2390 for attitude aspect with mean of 80, total score 2416 for knowledge aspect with mean of 81 , and total score 2457 for skill aspect with mean of 83 . Students' score in cycle II was 82 and thus categorized as "high". From the students' learning attitude, it was found that 25 people or $83 \%$ were active during the lesson study, 25 people or $83 \%$ of were cooperative, and 27 people or $90 \%$ were responsible for their own learning. From this result, it can be said that the ability of the students in some aspects like learning attitudes, knowledge, and writing skills in English was in high category and their cultural attitude was $50 \%$.

\section{Conclusion}

Based on the observation, action, and reflection, it can be concluded that the learning model through lesson study was very effective in improving the ability of students along with their better learning attitudes. For the progress and continuity of the quality of education, an important aspect is the learning attitudes element. There are some recommendations aimed at educational institutions, lecturers, and other researchers. For educational institutions, it is advisable to monitor and improve the use of authentic issues so that they can be reflected in the impact of learning outcomes. Furthermore, lecturers are encouraged to improve their ability to provide meaningful attitude and experience learning models.

\section{Conflict of interest statement and funding sources}

The authors declare that they have no competing interest. The study was financed by own funding.

\section{Statement of authorship}

The authors have a responsibility for the conception and design of the study. The authors have approved the final article.

Astuti, P., Wardana, I., Puspawati, D., \& Sukanadi, N. (2018). Interactive lesson study as a competence indicator of prospective English teachers. International Journal Of Social Sciences And Humanities (IJSSH), 2(2), 15-25. 


\section{Acknowledgments}

The authors would like to express their profound gratitude to all educators, teachers, and researchers for their kind help in conducting this study. Special thanks are dedicated to all colleagues for their support, their contribution, and their valuable input during the writing of this paper. The authors also express their deepest gratitude to all participants of this study who have spent a considerable length of time to complete this study. 


\section{References}

1. Azwar, S. (1997). Reliabilitas dan validitas. Yogyakarta: Pustaka Pelajar, 5. View in (Google Scholar)

2. Aminah, N. S. (2012). Dasar-Dasar Pengukuran dan Statistik pada Pembelajaran Fisika. Surakarta: UNS Press Jurnal Pendidikan Fisika (2013) Vol, 1.

View in (Google Scholar)

3. Ekawati, E. (2011). Pengembangan Instrumen Penilaian Pembelajaran Matematika Dasar. Yogyakarta: Kementerian Pendidikan Nasional.

View in (Google Scholar)

4. Maba, W. (2017). The Implementation of Education National Standard in the Instrument of School Accreditation of Bali Province Education Authority. International Research Journal of Engineering, IT \& Scientific Research (IRJEIS), 3(4), 1-6.

View in (Google Scholar)

5. Maba, W. (2017). Teacher's Perception on the Implementation of the Assessment Process in 2013 Curriculum. International Journal of Social Sciences and Humanities (IJSSH), 1(2), 1-9.

View in (Google Scholar)

6. Mantra, I. B. N. (2016). Promoting Primary School Teachers' Competence through Dynamic Interactive Workshop and Partnership. Journal of College and University. This is an open access article under the, 2455, 8028.

View in (Google Scholar)

7. Cahyani, I. A. M., Mantra, I. B. N., \& Wirastuti, I. G. A. P. (2018). Employing Picture Description to Assess the Students' Descriptive Paragraph Writing. Soshum: Jurnal Sosial dan Humaniora, 8(1), 86-93.

View in (Google Scholar)

8. Mantra, I. B. N., \& Maba, W. (2018). Enhancing The EFL Learners' Speaking Skill Through Folktales Based Instruction. In SHS Web of Conferences (Vol. 42, p. 00017). EDP Sciences.

View in (Google Scholar)

9. Mundilarto. (2010). Penilaian Hasil Belajar Fisika. Jogjakarta: P2IS FMIPA UNY.

View in (Google)

10. Arikunto, S. (1999). Dasar-dasar evaluasi pendidikan. Bumi Aksara.

View in (Google Scholar)

11. US, S. (2008). Pengaruh Bentuk Tes Formatif dan Kecerdasan Emosional terhadap Hasil Belajar Matematika.

View in (Google Scholar)

12. Yamtinah, Sri. (2009). Evaluasi Proses dan Hasil Belajar Kimia. UNS Press : Surakarta.

View in (Google Scholar)

13. Richards, J. C., \& Renandya, W. A. (Eds.). (2002). Methodology in language teaching: An anthology of current practice. Cambridge university press.

View in (Google Scholar)

Astuti, P., Wardana, I., Puspawati, D., \& Sukanadi, N. (2018). Interactive lesson study as a competence indicator of prospective English teachers. International Journal Of Social Sciences And Humanities (IJSSH), 2(2), 15-25. doi:10.29332/ijssh.v2n2.115 
14. Richards, J. C., \& Rodgers, T. S. (2014). Approaches and methods in language teaching. Cambridge university press.

View in (Google Scholar)

15. Sugiyono. (2012). Metode Penelitian Administrasi. Bandung: Alfabeta.

View in (Google Scholar) 


\section{Biography of Authors}

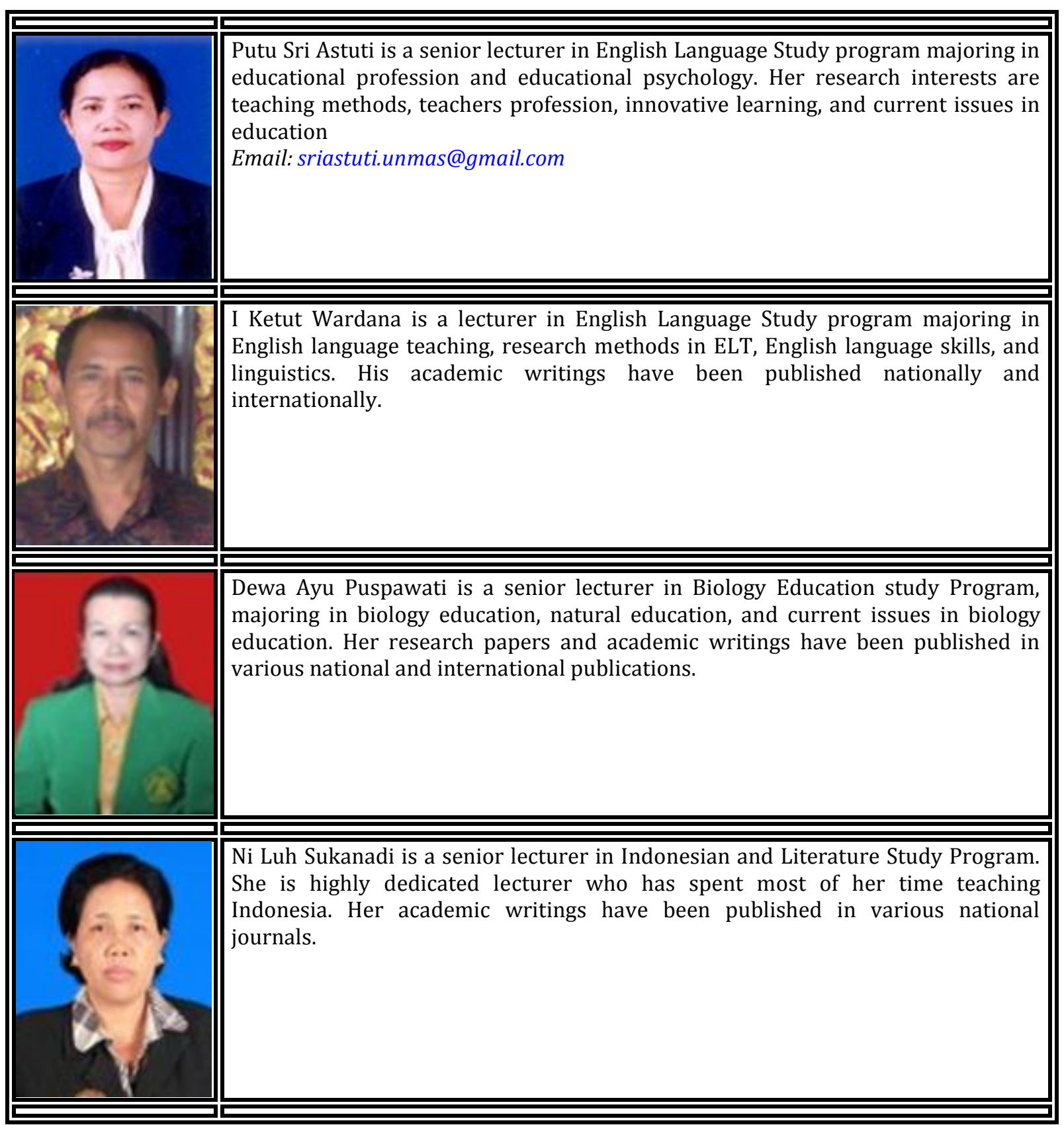

Astuti, P., Wardana, I., Puspawati, D., \& Sukanadi, N. (2018). Interactive lesson study as a competence indicator of prospective English teachers. International Journal Of Social Sciences And Humanities (IJSSH), 2(2), 15-25. doi:10.29332/ijssh.v2n2.115 